\title{
The response of extratropical cyclones in the Southern Hemisphere to stratospheric ozone depletion in the 20th century
}

\author{
Kevin M. Grise, ${ }^{*}$ Seok-Woo Son, ${ }^{2}$ Gustavo J. P. Correa' and Lorenzo M. Polvani ${ }^{1,3}$ \\ 'Lamont-Doherty Earth Observatory, Columbia University, Palisades, NY, USA \\ ${ }^{2}$ School of Earth and Environmental Sciences, Seoul National University, Seoul, South Korea \\ ${ }^{3}$ Department of Applied Physics and Applied Mathematics, and Department of Earth and Environmental Sciences, Columbia University, New York, \\ NY, USA
}

\section{* Correspondence to: Kevin M. Grise, Lamont-Doherty Earth Observatory, Columbia University, Palisades, NY 10964-8000 USA. \\ E-mail: kgrise@/deo.columbia.edu}

Received: 8 May 2013

Revised: 31 July 2013

Accepted: 12 August 2013

\begin{abstract}
This study explores the impact of Antarctic stratospheric ozone depletion on extratropical cyclones. Output from the Community Atmosphere Model is combined with a Lagrangian cyclone-tracking algorithm to identify the response of Southern Hemisphere extratropical cyclones to ozone and greenhouse gas forcings over the period 1960-2000. Stratospheric ozone depletion induces a significant poleward shift in cyclone frequency over the Southern Ocean, but has minimal influence on cyclone intensity and lifetime. The response of the cyclones to late 20th century greenhouse gas increases has similar characteristics, but falls within the range of natural variability in the model.
\end{abstract}

Keywords: extratropical cyclones; stratospheric ozone; Southern Hemisphere

\section{Introduction}

Extratropical cyclones not only govern many of the observed weather and precipitation patterns at midand high latitudes but also directly contribute to the heat, momentum, and moisture fluxes that play a central role in the general circulation of the atmosphere. Hence, it is important to understand how the frequency and intensity of the cyclones respond to anthropogenic forcings in the climate system. Numerous studies have investigated the effect on extratropical cyclones of projected increases in greenhouse gases over the 21st century using a wide range of methodologies (Geng and Sugi, 2003; Bengtsson et al., 2006; Lambert and Fyfe, 2006; Bengtsson et al., 2009; Ulbrich et al., 2009; Booth et al., 2012; Ulbrich et al., 2013), including recent analyses of the global climate model projections from phase 5 of the Coupled Model Intercomparison Project (CMIP5) (Chang et al., 2012; Mizuta, 2012; Zappa et al., 2013). One of the more robust findings in these studies is a poleward shift in the zonal-mean frequency of extratropical cyclones, particularly in the Southern Hemisphere (SH) (Kushner et al., 2001; Yin, 2005; Bengtsson et al., 2006; Chang et al., 2012). Changes in the intensity of the cyclones are, however, less clear and appear to reflect competing influences predicted in increasing greenhouse gas scenarios. The predicted decrease in the equator-to-pole surface temperature gradient and increase in tropospheric static stability might be expected to weaken the cyclones (Geng and Sugi, 2003), whereas the predicted increase in tropospheric moisture content and the equator-topole upper tropospheric temperature gradient might be expected to strengthen the cyclones (Booth et al., 2012; Mizuta, 2012).

Another key anthropogenic forcing in the $\mathrm{SH}$ is the depletion of Antarctic stratospheric ozone associated with chlorofluorocarbons. The emergence of the Antarctic ozone hole over the last two decades of the 20th century has strengthened the SH stratospheric polar vortex during austral spring and contributed to a poleward shift in the SH mid-latitude jet at tropospheric levels during austral summer. The linkage between the Antarctic ozone hole and changes in the SH tropospheric circulation has been documented both in observations and in climate model experiments (Thompson et al., 2011 for a recent review). In fact, modelling evidence suggests that the SH summertime tropospheric circulation changes associated with the ozone hole have been larger than those associated with increasing greenhouse gases over the second half of the 20th century (McLandress et al., 2011; Polvani et al., 2011a). Over the first half of the 21st century, the SH summertime tropospheric circulation changes associated with the recovery of the ozone hole are projected to counteract those associated with increasing greenhouse gases (Perlwitz et al., 2008; Son et al., 2008; Arblaster et al., 2011; Polvani et al., 2011b).

While the impact of Antarctic stratospheric ozone depletion on large-scale tropospheric circulation changes is by now well established, it is unknown whether ozone depletion affects the characteristics of individual extratropical cyclones, and whether its 
effects are distinct from those associated with increasing greenhouse gases. Several studies have estimated long-term trends in $\mathrm{SH}$ extratropical cyclones using reanalysis data sets (Simmonds and Keay, 2000; Wang et al., 2006; Wang et al., 2013), but large uncertainties remain because of temporal discontinuities in the observations assimilated into the reanalyses. Thus, in this study, we choose to examine the response of SH extratropical cyclones to stratospheric ozone depletion using a set of carefully designed climate model experiments, in which observed levels of ozone and greenhouse gases are independently prescribed during the pre-ozone hole (1960) and ozone hole (2000) periods. We identify individual cyclones in the model using a Lagrangian cyclone tracking algorithm and document how the characteristics of the cyclones respond to the ozone and greenhouse gas forcings. The results demonstrate that, during $\mathrm{SH}$ summer, the ozone depletion induces a robust poleward shift in the frequency of the cyclones but has little impact on their intensity: this is similar to, but larger than, the response of the cyclones to increasing greenhouse gases in the late 20th century.

\section{Methodology}

The results of this study are based on climate model experiments with the National Center for Atmospheric Research (NCAR) Community Atmosphere Model version 3 (CAM3) (Collins et al., 2006). The model is integrated with a standard T42 horizontal resolution (approximately $2.8^{\circ} \times 2.8^{\circ}$ latitude-longitude grid), 26 hybrid vertical levels, and a model top at $2.2 \mathrm{hPa}$. Sea surface temperatures and sea ice concentrations are prescribed using the Hadley Centre dataset (Rayner et al., 2003). Further details of the model configuration are described in Polvani et al. (2011a).

Here, we analyse 20 years of 6-hourly model output from the four experiments of Polvani et al. (2011a): (1) a control run in which ozone and greenhouse gases are set to 1960 levels (REF1960), (2) a run in which ozone is perturbed to 2000 levels (thus creating an ozone hole over Antarctica in the springtime) and greenhouse gases remain at 1960 levels (OZONE2000), (3) a run in which greenhouse gases are perturbed to 2000 levels and ozone remains at 1960 levels (GHG2000), and (4) a run in which both ozone and greenhouse gases are set to 2000 levels (BOTH2000). The ozone concentrations are taken from Cionni et al. (2011), and the greenhouse gas levels are taken from the historical forcings prescribed in CMIP3 models, as in Polvani et al. (2011a). (Nearly identical ozone and greenhouse gas concentrations were prescribed in the historical simulations of the CMIP5 models.) The sea surface temperatures and sea ice concentrations are specified using the mean of the 17-year period surrounding the date of the greenhouse gas forcing (i.e. 1952-1968 or 1992-2008). Throughout this paper, we use the term response to denote the difference of each perturbed run from the REF1960 run.

To identify extratropical cyclones in the model runs, we use the Lagrangian cyclone-tracking algorithm developed by Hodges (1994, 1995, 1999). Following Grise et al. (2013), the algorithm is applied to the 6-hourly relative vorticity field (filtered to wavenumbers 5-42) at the model level nearest $\sigma=0.85$. Details of the algorithm are provided in the above references. In brief, the algorithm minimizes a cost function to obtain the smoothest possible set of cyclone tracks that meet a minimum vorticity threshold of $1.0 \times 10^{-5} \mathrm{~s}^{-1}$ over the domain $25^{\circ} \mathrm{S}-90^{\circ} \mathrm{S}$. The tracks are subject to constraints on smoothness and maximum displacement between time steps. The track database is then filtered for cyclones with a minimum lifetime of 2 days, a minimum track length of $1000 \mathrm{~km}$, and a minimum peak vorticity of $3.0 \times 10^{-5} \mathrm{~s}^{-1}$. Developing cyclones are classified as systems with a growth rate exceeding $2.0 \times 10^{-5} \mathrm{~s}^{-1}$ day $^{-1}$.

\section{Results}

Prior to examining the response of SH extratropical cyclones to the ozone and greenhouse gas forcings, we first confirm the ability of our model to capture the climatological features of the cyclones. The left column of Figure 1 shows the observed summertime climatology of SH extratropical cyclones over the period 1992-2011 as derived from the European Centre for Medium-Range Weather Forecasts (ECMWF) Interim reanalysis data set (ERA-Interim) (Dee et al., 2011). The cyclones are most frequent in a circumpolar band over the Southern Ocean centred near $53^{\circ} \mathrm{S}$ (Figure 1 , top left). The cyclone frequency is approximately zonally symmetric, with localized maxima occurring over the southern Atlantic Ocean, southeastern Indian Ocean, and southeastern Pacific Ocean. The mean intensity of the cyclones is largest east of South America, in the southern Indian Ocean, and east of New Zealand (Figure 1, middle left). The cyclones primarily develop over strong meridional sea surface temperature gradients in the mid-latitude Southern Ocean and near the eastern coastlines of South America, Australia, and New Zealand (Figure 1, bottom left). The cyclones primarily decay over the high-latitude Southern Ocean near the coastline of Antarctica (not shown). Overall, the observed climatology derived here compares well with those shown in previous studies (Hoskins and Hodges, 2005).

The right column of Figure 1 shows the summertime climatology of $\mathrm{SH}$ extratropical cyclones from our model. Here, we use the BOTH2000 integration to best match the period from the reanalysis. Overall, the model reproduces the observed climatology (Figure 1, left) with reasonable accuracy. Recall that both datasets were truncated to the same horizontal resolution (wavenumbers 5-42) for the cyclone tracking. The most notable difference between the 


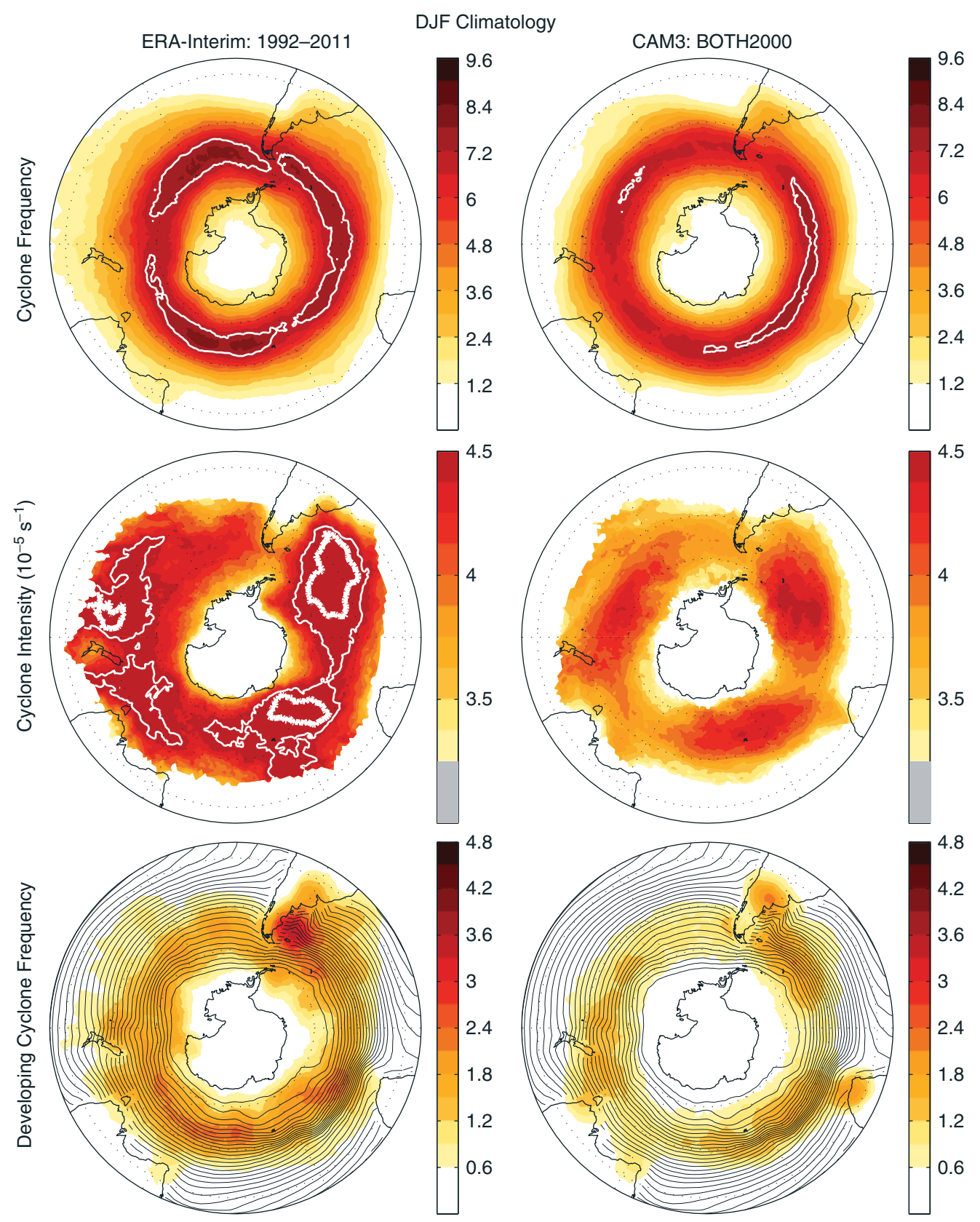

Figure I. December-February (DJF) climatology of Southern Hemisphere extratropical cyclones for (left column) 1992-20I I ERA-Interim reanalysis and (right column) the BOTH2000 model integration. Cyclones are identified using the relative vorticity field at the model level nearest $\sigma=0.85$, the Hodges (1994) algorithm, and the filtering criteria of Grise et al. (20I3). Cyclones are assigned to a 500-km radius region surrounding the vorticity maximum. (Top) Cyclone frequency. (Middle) Cyclone intensity (for grid points where a cyclone is present for at least 50 of the 60 months). (Bottom) Developing cyclone frequency. The shading interval is (top) 0.6 cyclones month ${ }^{-1}$, (middle) $1.25 \times 10^{-6} \mathrm{~s}^{-1}$, and (bottom) 0.3 cyclones month ${ }^{-1}$. The thin white lines highlight the (top) 7.2 cyclones month ${ }^{-1}$ and (middle) $4.5 \times 10^{-5} \mathrm{~s}^{-1}$ contours, and the thick white lines highlight the (middle) $4.75 \times 10^{-5} \mathrm{~s}^{-1}$ contour. In the bottom panels, the thin contours display the observed DJF-mean sea surface temperatures prescribed in the BOTH2000 model integration (contour interval: IK).

reanalysis and model results is the underestimate in the frequency and intensity of cyclones by the model. This underestimate is attributable, at least in part, to the lower native resolution of the model (Jung et al., 2006); similar underestimates in SH cyclone intensity during DJF are also found in CMIP5 models (Chang et al., 2012). Additional differences between the reanalysis and model results include: (1) an equatorward bias in the model cyclone frequency near New
Zealand, (2) excessive cyclones in the model near South Africa, and (3) missing cyclone development in the model south of Australia (Figure 1, bottom). Despite these limitations, we submit that CAM3 provides a satisfactory representation of SH extratropical cyclones for our experiments.

To isolate the impact of ozone forcing on SH extratropical cyclones, we compare the summertime climatology of the cyclones from the REF1960 and 

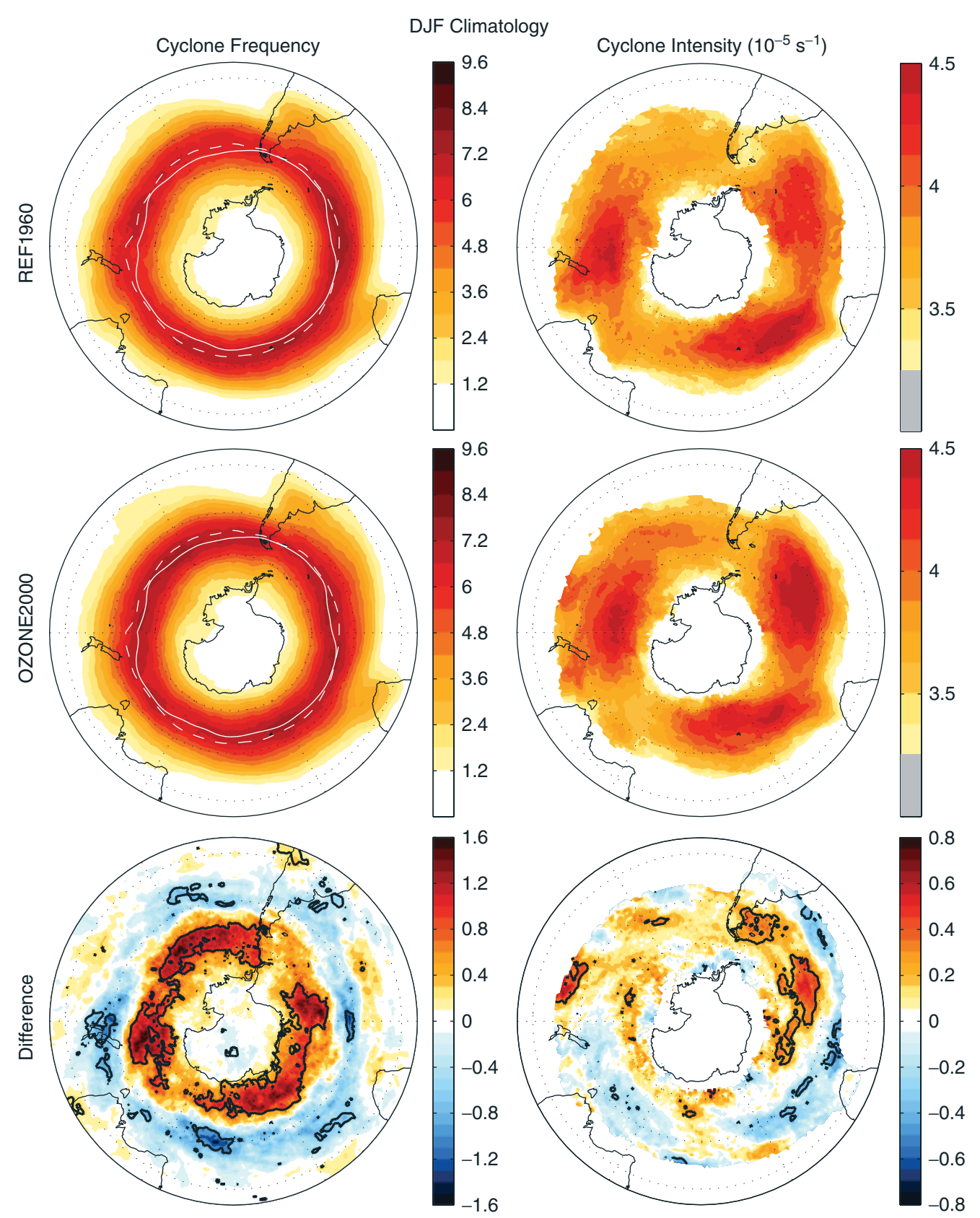

Figure 2. DJF climatology of Southern Hemisphere extratropical cyclones for the (top row) REFI960 and (middle row) OZONE2000 model integrations. The left column displays the cyclone frequency (as in the top row of Figure I). The thin white lines denote the latitude of the maximum at each longitude for the (dashed) REFI 960 and (solid) OZONE2000 integrations. The right column displays the cyclone intensity (as in the middle row of Figure I). The bottom row shows the difference between the OZONE2000 and REFI 960 panels. Regions that are 95\% significant via a Student's t-test are denoted by thick bolded outlines. The shading interval in the bottom row is (left) 0.1 cyclones month ${ }^{-1}$ and (right) $5.0 \times 10^{-7} \mathrm{~s}^{-1}$.

OZONE2000 model integrations (Figure 2). Recall that ozone is the only forcing that differs between these two experiments; greenhouse gases, sea surface temperatures, and sea ice concentrations are fixed at 1960 levels in both experiments. Overall, the climatologies from the two runs are similar to those shown in Figure 1, but Antarctic stratospheric ozone depletion leads to several notable differences in SH cyclones (Figure 2, bottom row). First, the latitude where extratropical cyclones are most frequent shifts $\sim 2^{\circ}$ poleward (Figure 2, left, white lines). Second, the frequency of cyclones increases over the high-latitude Southern
Ocean (Figure 2, bottom left). Third, there is some suggestion that the intensity of cyclones tracking eastward from South America increases (Figure 2, bottom right). Finally, the frequency of developing cyclones weakly increases southwest of South America and decreases near South Africa, southeastern Australia, and New Zealand (not shown).

Figure 3 decomposes the results from Figure 2 (bottom row) into three terciles (i.e. approximately equal-sized populations of cyclones) based on the maximum intensity of each cyclone: weak cyclones $\left(3.0 \times 10^{-5} \mathrm{~s}^{-1}-4.3 \times 10^{-5} \mathrm{~s}^{-1}\right)$, moderate cyclones 


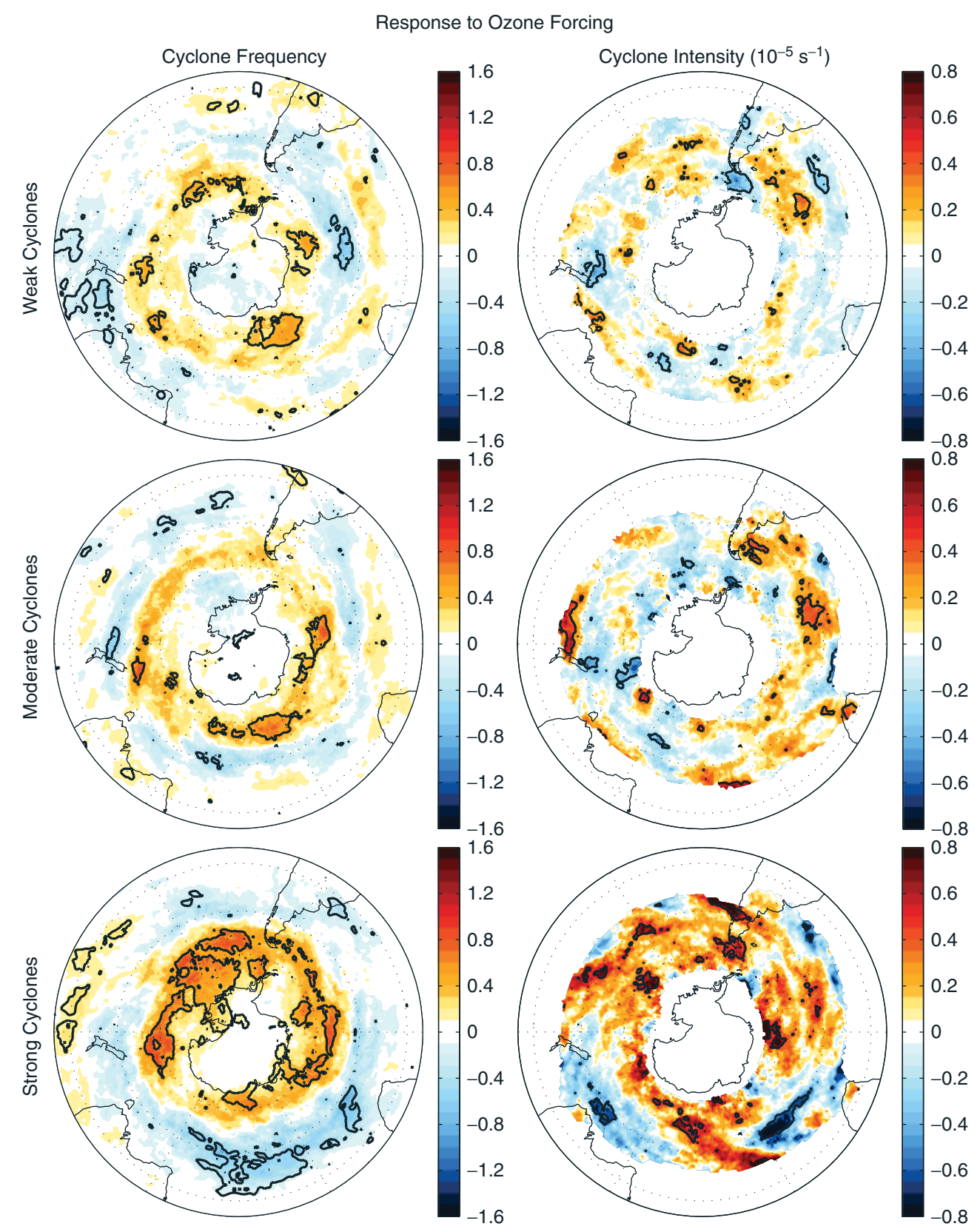

Figure 3. As in the bottom row of Figure 2, but separated into (top row) cyclones of weak maximum intensity $\left(3.0 \times 10^{-5} \mathrm{~s}^{-1}-4.3 \times 10^{-5} \mathrm{~s}^{-1}\right)$, (middle row) cyclones of moderate maximum intensity $\left(4.3 \times 10^{-5} \mathrm{~s}^{-1}-5.9 \times 10^{-5} \mathrm{~s}^{-1}\right)$, and (bottom row) cyclones of strong maximum intensity (greater than $5.9 \times 10^{-5} \mathrm{~s}^{-1}$ ). Cyclone intensity is shown for grid points where a cyclone is present for at least 30 of the 60 months.

$\left(4.3 \times 10^{-5} \mathrm{~s}^{-1}-5.9 \times 10^{-5} \mathrm{~s}^{-1}\right)$, and strong cyclones (greater than $5.9 \times 10^{-5} \mathrm{~s}^{-1}$ ). The results reveal that the response of the SH extratropical cyclones to the ozone forcing does not arise from a single category of cyclones. Weak, moderate, and strong cyclones all experience a poleward shift in frequency and a slight intensification east of South America. The most significant response in cyclone frequency arises from the strongest cyclones (Figure 3, bottom left), whereas the most significant response in cyclone intensity over the South Atlantic Ocean arises largely from weak to moderate cyclones (Figure 3, right).

The quantitative response of the $\mathrm{SH}$ summertime cyclones to the ozone forcing is summarized in
Table I. The most robust response of the cyclones is the significant decrease in frequency over the $35^{\circ} \mathrm{S}-45^{\circ} \mathrm{S}$ latitude band and increase in frequency over the $55^{\circ} \mathrm{S}-65^{\circ} \mathrm{S}$ latitude band (Figure 2). The strongest cyclones also experience a significant increase in frequency over the $55^{\circ} \mathrm{S}-65^{\circ} \mathrm{S}$ latitude band (Figure 3 ). The poleward shift in cyclone frequency closely mirrors the poleward shift in the SH mid-latitude tropospheric jet (cf. Figure 4 of Polvani et al., 2011a). Because the translation speed of cyclones closely follows the lower tropospheric mean flow (Hoskins and Hodges, 2005), the cyclones at higher latitudes experience a significant increase in translation speed, and 

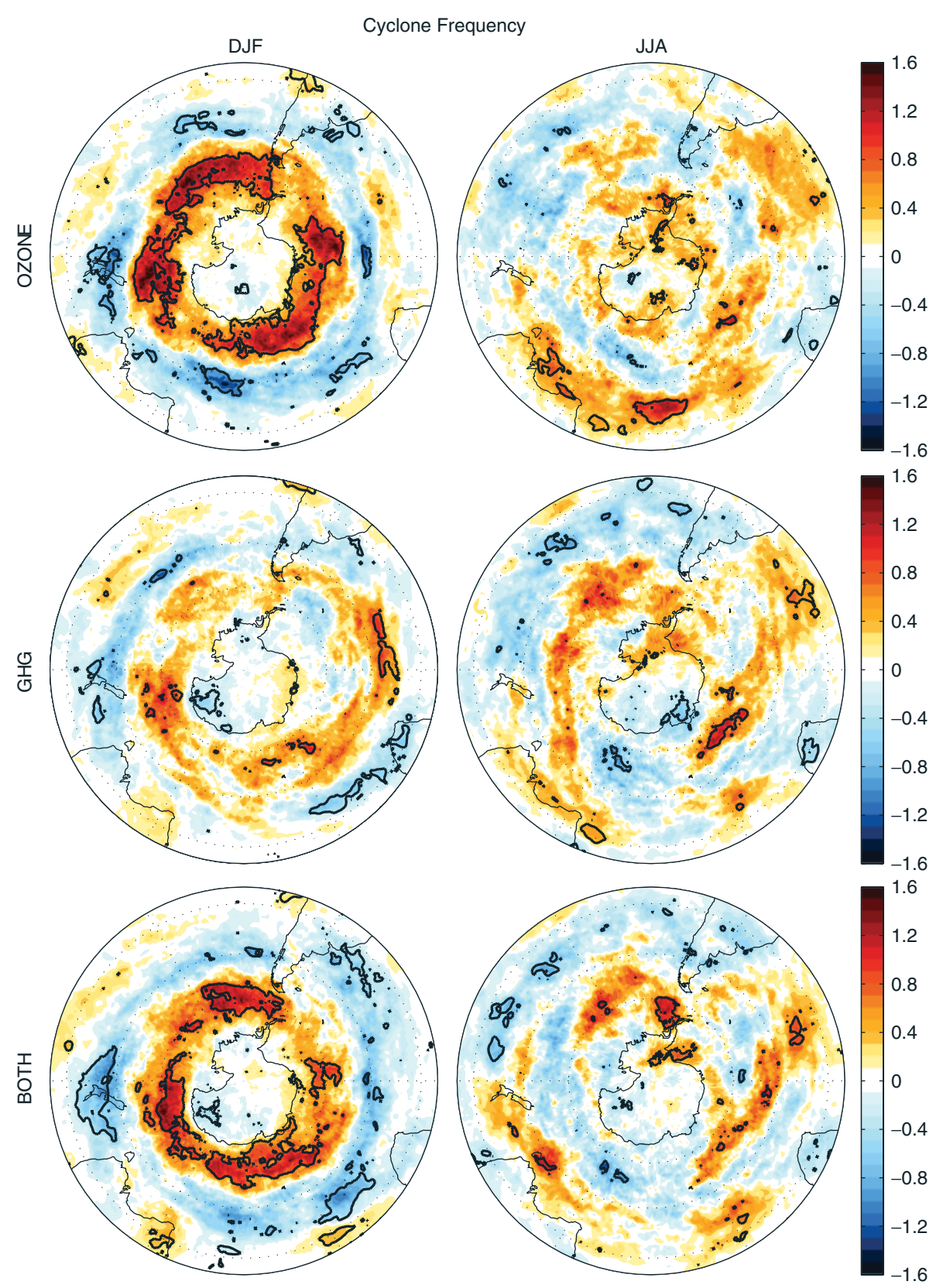

Figure 4. Cyclone frequency response to (top row) ozone forcing, (middle row) greenhouse gas forcing, and (bottom row) both forcings. The left column is for the DJF climatology, and the right column is for the June-August (JJA) climatology. Regions that are $95 \%$ significant via a Student's $t$-test are denoted by thick bolded outlines. The shading interval is 0.1 cyclones month ${ }^{-1}$.

the cyclones at lower latitudes experience a significant decrease in translation speed. The ozone forcing has little effect on the lifetime of the cyclones, so the cyclones at high latitudes travel on average $250 \mathrm{~km}$ farther in the OZONE2000 run.

Apart from regional features that might be model dependent (Figure 2, bottom right), the intensity of the cyclones is only weakly affected by the ozone forcing. In fact, other than a slight increase in translation speed, there is no significant net effect of the ozone forcing on cyclone properties over the entire $\mathrm{SH}$ mid-latitudes $\left(35^{\circ} \mathrm{S}-65^{\circ} \mathrm{S}\right)$; that is, the response of the cyclones to the ozone forcing is best characterised as a poleward shift. Because the ozone forcing strongly affects the meridional temperature gradient in the upper troposphere and lower stratosphere, our results suggest a larger role for lower tropospheric temperature gradients and moisture in governing cyclone intensity changes in our model.

Having documented the impact of ozone depletion on SH extratropical cyclones, we now compare that response to the cyclones' response to increasing greenhouse gases. Figure 4 shows the responses of the cyclones to the ozone forcing (OZONE2000), greenhouse gas forcing (GHG2000), and both forcings (BOTH2000) for both the austral winter and summer seasons. During the winter months, the responses of the cyclones to all forcings are difficult to interpret and not statistically significant (Figure 4, right 
Table I. December-February extratropical cyclone characteristics in selected latitude bands. In each cell, the leftmost value lists the mean value from the REFI960 integration, and the subsequent italicized values list the response to the ozone forcing, greenhouse gas forcing, and both forcings. Responses that are $95 \%$ significant are listed in bold type. The bottom row of cells is limited to cyclones of strong maximum intensity (greater than $5.9 \times 10^{-5} \mathrm{~s}^{-1}$ ).

\begin{tabular}{|c|c|c|c|}
\hline & $35^{\circ} \mathrm{S}-45^{\circ} \mathrm{S}$ & $45^{\circ} \mathrm{S}-55^{\circ} \mathrm{S}$ & $55^{\circ} \mathrm{S}-65^{\circ} \mathrm{S}$ \\
\hline Frequency (cyclones month ${ }^{-1}$ ) & $42.07,-\mathbf{2 . 2 6},-0.95,-\mathbf{2 . 6 6}$ & $55.45,-0.61,+0.55,+0.29$ & $39.73,+\mathbf{4 . 0 2},+0.83,+\mathbf{2 . 8 7}$ \\
\hline Intensity $\left(10^{-5} \mathrm{~s}^{-1}\right)$ & $3.65,+0.00,-0.04,-0.05$ & $4.05,+0.04,+0.03,+0.02$ & $3.92,+\mathbf{0 . 0 9},+0.04,+0.07$ \\
\hline Lifetime (days) & $5.33,-0.03,+0.05,-0.05$ & $5.37,-0.03,-0.01,-0.11$ & $5.75,-0.12,+0.03,-\mathbf{0 . 1 6}$ \\
\hline Track length $(\mathrm{km})$ & $5903,+45.5,+132,-33.9$ & $5917,+\mathbf{2 4 9 . 4},+80.5,+142.4$ & $5714,+\mathbf{2 5 3 . 5},+157.4,+\mathbf{2 3 3} . \mathbf{I}$ \\
\hline Speed of movement $\left(\mathrm{ms}^{-1}\right)$ & $16.37,-\mathbf{0 . 4 3},-0.09,-\mathbf{0 . 6 2}$ & $\mid 6.71,+I .25,+0.35,+I .20$ & $10.45,+1.46,+0.53,+1.47$ \\
\hline Strong cyclone frequency (cyclones month ${ }^{-1}$ ) & $16.13,-1.04,-0.47,-1.74$ & $22.58,+0.17,+0.54,+0.03$ & $16.82,+\mathbf{2 . 7 4},+1.22,+\mathbf{2 . 1 2}$ \\
\hline
\end{tabular}

column). During the summer months, the response of the cyclones to the ozone forcing is dominant over the 1960-2000 period (Figure 4, left column). There is some suggestion that increasing greenhouse gases also contribute to a poleward shift in cyclone frequency (Figure 4, middle left), as noted in previous studies (Bengtsson et al., 2006; Chang et al., 2012). However, the response of the $\mathrm{SH}$ extratropical cyclones to the greenhouse gas forcing is neither as robust nor as pronounced as their response to the ozone forcing. Interestingly, we note that the qualitative responses of the cyclones to the ozone and greenhouse gas forcings have very similar character (Table I), presumably because both forcings tend to drive the SH mid-latitude westerly jet in the same direction.

\section{Summary}

In this study, we have examined the response of SH extratropical cyclones to stratospheric ozone depletion and increasing greenhouse gases over the second half of the 20th century. Our model experiments have indicated that, over the 1960-2000 period, the response of the summertime extratropical cyclones to stratospheric ozone depletion is similar in structure but larger in magnitude than their response to increasing greenhouse gases. Both forcings are associated with a poleward shift in cyclone frequency over the Southern Ocean, minimal changes in cyclone intensity and duration, and an increase in cyclone translation speed and track length at higher latitudes.

While the greenhouse gas forcing over the latter half of the 20th century is not strong enough to yield a robust response in SH extratropical cyclones in our model, it is expected that the influence of increasing greenhouse gases on $\mathrm{SH}$ cyclones will become more robust (Geng and Sugi, 2003; Bengtsson et al., 2006; Chang et al., 2012). However, the recovery of the Antarctic ozone hole in the 21st century is expected to induce oppositely signed changes in the SH tropospheric circulation and cyclones to those discussed here (Perlwitz, 2011). Consequently, any influence of increasing greenhouse gases on $\mathrm{SH}$ extratropical cyclones will be most apparent during the austral winter months.

\section{Acknowledgements}

We thank J. F. Booth for helpful comments and assistance with the cyclone tracking algorithms. We also thank K. I. Hodges for providing us with his tracking algorithm. K. M. G. and L. M. P. were supported by a grant from the National Science Foundation to Columbia University. S. W. S. was supported by the Korea Polar Research Institute (KOPRI) grant under Project PE13010.

\section{References}

Arblaster JM, Meehl GA, Karoly DJ. 2011. Future climate change in the Southern Hemisphere: competing effects of ozone and greenhouse gases. Geophysical Research Letters 38: L02701 10.1029/2010GL045384.

Bengtsson L, Hodges KI, Roeckner E. 2006. Storm tracks and climate change. Journal of Climate 19: 3518-3543.

Bengtsson L, Hodges KI, Keenlyside N. 2009. Will extratropical storms intensify in a warmer climate? Journal of Climate 22: 2276-2301.

Booth JF, Wang S, Polvani L. 2012. Midlatitude storms in a moister world: lessons from idealized baroclinic life cycle experiments. Climate Dynamics, DOI: 10.1007/s00382-012-1472-3.

Chang EKM, Guo Y, Xia X. 2012. CMIP5 multimodel ensemble projection of storm track change under global warming. Journal of Geophysical Research 117: D23118 10.1029/2012JD018578.

Cionni I, Eyring V, Lamarque JF, Randel WJ, Stevenson DS, Wu F, Bodeker GE, Shepherd TG, Shindell DT, Waugh DW. 2011. Ozone database in support of CMIP5 simulations: results and corresponding radiative forcing. Atmospheric Chemistry and Physics 11: $11267-11292$.

Collins WD, Rasch PJ, Boville BA, Hack JJ, McCaa JR, Williamson DL, Briegleb BP, Bitz CM, Lin S-J, Zhang M. 2006. The formulation and atmospheric simulation of the Community Atmosphere Model Version 3 (CAM3). Journal of Climate 19: 2144-2161.

Dee DP, Uppala SM, Simmons AJ, Berrisford P, Poli P, Kobayashi S, Andrae U, Balmaseda MA, Balsamo G, Bauer P, Bechtold P, Beljaars ACM, van de Berg L, Bidlot J, Bormann N, Delsol C, Dragani R, Fuentes M, Geer AJ, Haimberger L, Healy SB, Hersbach H, Hólm EV, Isaksen L, Kållberg P, Köhler M, Matricardi M, McNally AP, Monge-Sanz BM, Morcrette J-J, Park B-K, Peubey C, de Rosnay P, Tavolato C, Thépaut J-N, Vitart J. 2011. The ERA-interim reanalysis: configuration and performance of the data assimilation system. Quarterly Journal of the Royal Meteorological Society 137: 553-597.

Geng Q, Sugi M. 2003. Possible change of extratropical cyclone activity due to enhanced greenhouse gases and sulfate aerosols - study with a high-resolution AGCM. Journal of Climate 16: 2262-2274.

Grise KM, Son S-W, Gyakum JR. 2013 in press. Intraseasonal and interannual variability in North American storm tracks and its relationship to equatorial Pacific variability. Monthly Weather Review, DOI: 10.1175/MWR-D-12-00322.1. 
Hodges KI. 1994. A general method for tracking analysis and its application to meteorological data. Monthly Weather Review 122: 2573-2586.

Hodges KI. 1995. Feature tracking on the unit sphere. Monthly Weather Review 123: 3458-3465.

Hodges KI. 1999. Adaptive constraints for feature tracking. Monthly Weather Review 127: 1362-1373.

Hoskins BJ, Hodges KI. 2005. A new perspective on Southern Hemisphere storm tracks. Journal of Climate 18: 4108-4129.

Jung T, Gulev SK, Rudeva I, Soloviov V. 2006. Sensitivity of extratropical cyclone characteristics to horizontal resolution in the ECMWF model. Quarterly Journal of the Royal Meteorological Society 132: 1839-1857.

Kushner PJ, Held IM, Delworth TL. 2001. Southern Hemisphere atmospheric circulation response to global warming. Journal of Climate 14: 2238-2249.

Lambert SJ, Fyfe JC. 2006. Changes in winter cyclone frequencies and strengths simulated in enhanced greenhouse warming experiments: results from the models participating in the IPCC diagnostic exercise. Climate Dynamics 26: 713-728.

McLandress C, Shepherd TG, Scinocca JF, Plummer DA, Sigmond M, Jonsson AI, Reader MC. 2011. Separating the dynamical effects of climate change and ozone depletion. Part II: Southern Hemisphere troposphere. Journal of Climate 24: 1850-1868.

Mizuta R. 2012. Intensification of extratropical cyclones associated with the polar jet change in the CMIP5 global warming projections. Geophysical Research Letters 39: L19707 10.1029/2012GL053032.

Perlwitz J. 2011. Tug of war on the jet stream. Nature Climate Change 1: 29-31.

Perlwitz J, Pawson S, Fogt RL, Nielsen JE, Neff WD. 2008. Impact of stratospheric ozone hole recovery on Antarctic climate. Geophysical Research Letters 35: L08714, 10.1029/2008GL033317.

Polvani LM, Waugh DW, Correa GJP, Son S-W. 2011a. Stratospheric ozone depletion: the main driver of twentieth century atmospheric circulation changes in the Southern Hemisphere. Journal of Climate 24: 795-812.

Polvani LM, Previdi M, Deser C. 2011b. Large cancellation, due to ozone recovery, of future Southern Hemisphere atmospheric circulation trends. Geophysical Research Letters 38: L04707 10.1029/2011GL046712.

Rayner NA, Parker DE, Horton EB, Folland CK, Alexander LV, Rowell DP, Kent EC, Kaplan A. 2003. Global analyses of sea surface temperature, sea ice, and night marine air temperature since the late nineteenth century. Journal of Geophysical Research 108: 4407, DOI: 10.1029/2002JD002670.

Simmonds I, Keay K. 2000. Variability of Southern Hemisphere extratropical cyclone behavior, 1958-97. Journal of Climate 13: $550-561$.

Son S-W, Polvani LM, Waugh DW, Akiyoshi H, Garcia R, Kinnison D, Pawson S, Rozanov E, Shepherd TG, Shibata K. 2008. The impact of stratospheric ozone recovery on the Southern hemisphere westerly jet. Science 320: 1486-1489.

Thompson DWJ, Solomon S, Kushner PJ, England MH, Grise KM, Karoly DJ. 2011. Signatures of the Antarctic ozone hole in Southern Hemisphere surface climate change. Nature Geoscience 4: 741-749.

Ulbrich U, Leckebusch GC, Pinto JG. 2009. Extra-tropical cyclones in the present and future climate: a review. Theoretical and Applied Climatology 96: 117-131.

Ulbrich U, Leckebusch GC, Grieger J, Schuster M, Akperov M, Bardin MY, Feng Y, Gulev S, Inatsu M, Keay K, Kew SF, Liberato MLR, Lionello P, Mokhov II, Neu U, Pinto JG, Raible CC, Reale M, Rudeva I, Simmonds I, Tilinina ND, Trigo IF, Ulbrich S, Wang XL, Wernli H, IMILAST Team. 2013. Are greenhouse gas signals of Northern Hemisphere winter extratropical cyclone activity dependent on the identification and tracking algorithm? Meteorologische Zeitschrift 22: 61-68.

Wang XL, Swail VR, Zwiers FW. 2006. Climatology and changes of extratropical cyclone activity: comparison of ERA-40 with NCEP-NCAR reanalysis for 1958-2001. Journal of Climate 19: 3145-3166.

Wang XL, Feng Y, Compo GP, Swail VR, Zwiers FW, Allan RJ, Sardeshmukh PD. 2013. Trends and low frequency variability of extra-tropical cyclone activity in the ensemble of twentieth century reanalysis. Climate Dynamics 40: 2775-2800.

Yin JH. 2005. A consistent poleward shift of the storm tracks in simulations of 21 st century climate. Geophysical Research Letters 32: L18701, 10.1029/2005GL023684.

Zappa G, Shaffrey LC, Hodges KI, Sansom PG, Stephenson DB. 2013. A multi-model assessment of future projections of North Atlantic and European extratropical cyclones in the CMIP5 climate models. Journal of Climate 26: 5846-5862, DOI: 10.1175/JCLI-D12-00573.1. 